\title{
Oculocutaneous albinism type 5
}

INSERM

\section{Source}

INSERM. (1999). Orphanet: an online rare disease and orphan drug data base.

Oculocutaneous albinism type 5. ORPHA:370091

Oculocutaneous albinism type 5 (OCA5) is a type of oculocutaneous albinism found in one Pakistani family to date, characterized by white skin, golden hair, photophobia,

nystagmus, foveal hypoplasia and impaired visual acuity, that affects males and females equally, and that has been mapped to a locus on chromosome 4 q24 but whose gene has not yet been discovered. 